\title{
Rancang Bangun Aplikasi Penentuan Kelayakan Pemberian Pinjaman Kepada Pensiun Menggunakan Metode Weighted Product
}

\author{
Kezia Tirza Naramessakh, Cahyo Prianto \\ Program Studi DIV Teknik Informatika, Politeknik Pos Indonesia, Bandung, Indonesia \\ Email: ${ }^{1}$ kezianaramessakh@gmail.com, ${ }^{2}$ cahyoprianto@poltekpos.ac.id
}

\begin{abstract}
Abstrak
Dalam mendukung jalannya operasional pada PT. Pos Indonesia, salah satunya adalah menawarkan kepada para pensiunan seperti tabungan pensiun dan kredit pensiun. Kredit merupakan penyediaan uang atau tagihan berdasarkan persetujuan atau kesepakatan pinjam meminjam antara suatu perusahaan dengan pihak lain. Dalam memberikan kredit pensiun harus tepat dan akurat kepada pensiunan yang berhak atau layak untuk mendapatkan pinjaman kredit. Maka penulis membuat aplikasi penentuan kelayakan pemberian pinjaman agar bisa mempermudah dalam menentukan pensiunan yang layak untuk diberikan pinjaman kredit. Penelitian ini menggunakan metode Weighted Product (WP), yaitu salah satu metode pengambilan keputusan. Dengan menggunakan metode Weighted Product dapat membantu dalam pengambilan keputusan pemberian pinjaman dengan dilakukannya proses peringkatan yang akan menentukan alternatif terbaik dari pensiunan. Penulis menggunakan lima kriteria yaitu, besar gaji, jumlah pinjaman, usia, jangka waktu kredit, dan kredit ke-berapa. Penbuatan aplikasi penentuan kelayakan pemberian pinjaman kepada pensiun ini berbasis website menggunakan framework code igniter. Untuk perancangan atau pemodelan aplikasi ini menggunakan UML (Unified Modeling Language). Penelitian ini menghasilkan aplikasi yang membantu dalam menentukan pensiun yang layak untuk diberikan pinjaman kredit pensiun menggunakan Weighted Product.
\end{abstract}

Kata Kunci: Weighted Product, Pinjaman, Pensiun, Code Igniter

\section{Abstract}

In supporting the operation of PT. Pos Indonesia, one of which is offering retirees such as pension savings and pension credit. Credit is the provision of money or bills based on an agreement or loan agreement between a company and another party. In providing pension credit, it must be accurate and accurate for retirees who are entitled or eligible to get a loan. So the author makes an application to determine the feasibility of lending in order to make it easier to determine which retirees are eligible to be given a credit loan. This study uses the Weighted Product (WP) method, which is one method of decision making. By using the Weighted Product method can help in making lending decisions by doing a ranking process that will determine the best alternative from retirees. The author uses five criteria, namely, the amount of salary, loan amount, age, credit period, and what credit. The application of determining the feasibility of lending to pensions is based on a website using the code igniter framework. For designing or modeling this application uses UML (Unified Modeling Language). This research resulted in an application that helped in determining a proper pension to be given a pension loan using Weighted Product.

Keywords: Weighted Product, Loan, Pension, Code Igniter

\section{PENDAHULUAN}

Kredit merupakan penyediaan uang atau tagihan yang dapat dipersamakan dengan itu, berdasarkan persetujuan atau kesepakatan pinjam meminjam antara suatu perusahaan dengan pihak lain yang mewajibkan pihak peminjam untuk melunasi kreditnya setelah jangka waktu tertentu dengan jumlah uang, imbalan atau pembagian hasil keuntungan[1]. PT. Pos Indonesia menawarkan kepada para pensiun seperti tabungan pensiun dan kredit pensiun. Dimana pensiun merupakan jaminan hari tua dan sebagai balas jasa terhadap pegawai beserta keluarganya yang telah bertahun-tahun mengabdikan dirinya kepada Negara[2]. Pada kegiatan kredit pensiun Pos memiliki prosedur yang harus dilalui apabila akan mengajukan kredit dan proses pemberian kredit PT. Pos Indonesia perlu memperhatikan syarat-syarat untuk para pensiunan yang mengajukan kredit pensiun pada PT. Pos Indonesia[3]. Dalam memberikan kredit pensiun harus tepat dan akurat karena sangat berpengaruh pada perusahaan untuk menentukan pensiunan yang mendapatkan pinjaman kredit.

Berdasarkan permasalahan di atas maka diperlukan suatu aplikasi untuk pengambilan keputusan kelayakan pemberian kredit pensiun yang mampu memberikan keputusan pemberian kredit pensiun yang akurat dan tepat serta menghemat waktu dalam penentuan kelayakan kredit. Oleh sebab itu, dibuat sebuah aplikasi dengan menggunakan metode Weighted Product yang mampu menentukan sebuah keputusan bagi pensiun yang berhak mendapatkan pinjaman kredit. Metode Weighted Product (WP) merupakan salah satu metode penyelesaian untuk masalah Multi Attribute Decision Making (MADM). Multi Attribute Decision Making (MADM) adalah keputusan analisis multi kriteria yang popular dan merupakan metode pengambilan keputusan multi kriteria[4] Dalam penelitian sebelumnya, metode weighted product FMADM digunakan untuk dapat memberi keputusan kelayakan pemberian kredit bagi calon peminjam[5]. Dan pengambilan keputusan dalam kelayakan penerima bantuan beras masyarakat miskin[6], serta pengambilan keputusan untuk memilih calon rekrutmen pegawagi baru[7]

Pembuatan aplikasi kelayakan pemberian kredit pensiun ini menggunakan framework code igniter. Code igniter adalah sebuah framework PHP (Hypertext Prepocessor) yang dapat mempercepat pengembang untuk membuat sebuah aplikasi website. Dilengkapi banyak library dan helper yang berguna di dalamnya dan tentunya mempermudah proses development[8]. Code igniter akan mempermudah dan mempercepat pembuatan maupun 
pengembangan website dinamis tanpa harus kesulitan membuat desain. Untuk perancangan atau pemodelan aplikasi ini menggunakan UML (Unified Modeling Language). Dengan menggunakan UML dapat dibuat model untuk semua jenis aplikasi piranti lunak, dimana aplikasi tersebut dapat berjalan pada piranti keras, sistem operasi dan jaringan apapun, serta ditulis dalam bahasa pemrograman apapun[9]. Maka dari pembuatan aplikasi ini dengan menggunakan metode weighted product akan membantu dalam memberikan hasil kelayakan pinjaman kredit.

\section{METODE PENELITIAN}

\subsection{Diagram Alur Metodologi Penelitian}

Melakukan serangkaian cara atau langkah untuk memecahkan suatu masalah dengan berdasarkan pada data yang didapat dari hasil pada sebuah penelitian. Penelitian merupakan suatu penyelidikan yang sistematis untuk meningkatkan sejumlah pengetahuan, juga merupakan suatu usaha yang sistematis dan terorganisasi untuk menyelidiki masalah tertentu yang memerlukan jawaban.

Tahapan Metodologi penelitian yang akan digunakan yaitu identifikasi masalah, tujuan penelitian, pengumpulan data yaitu berupa studi literatur dan wawancara, data penelitian, analisis data untuk menentukan kriteria yang akan digunakan dan menentukan alternatif yang akan digunakan, pengolahan data dengan metode Weigthed Product, setelah itu akan ada proses mendesain sistem, kemudian implementasi sistem, serta pengujian dan penggunaan sistem. Dan hasil akhirnya akan berupa kesimpulan dan saran dari analisis data maupun sistem yang menerapkan metode weighted product. Berikut tahapan dalam melakukan penelitian ini digambarkan dalam gambar 1 .

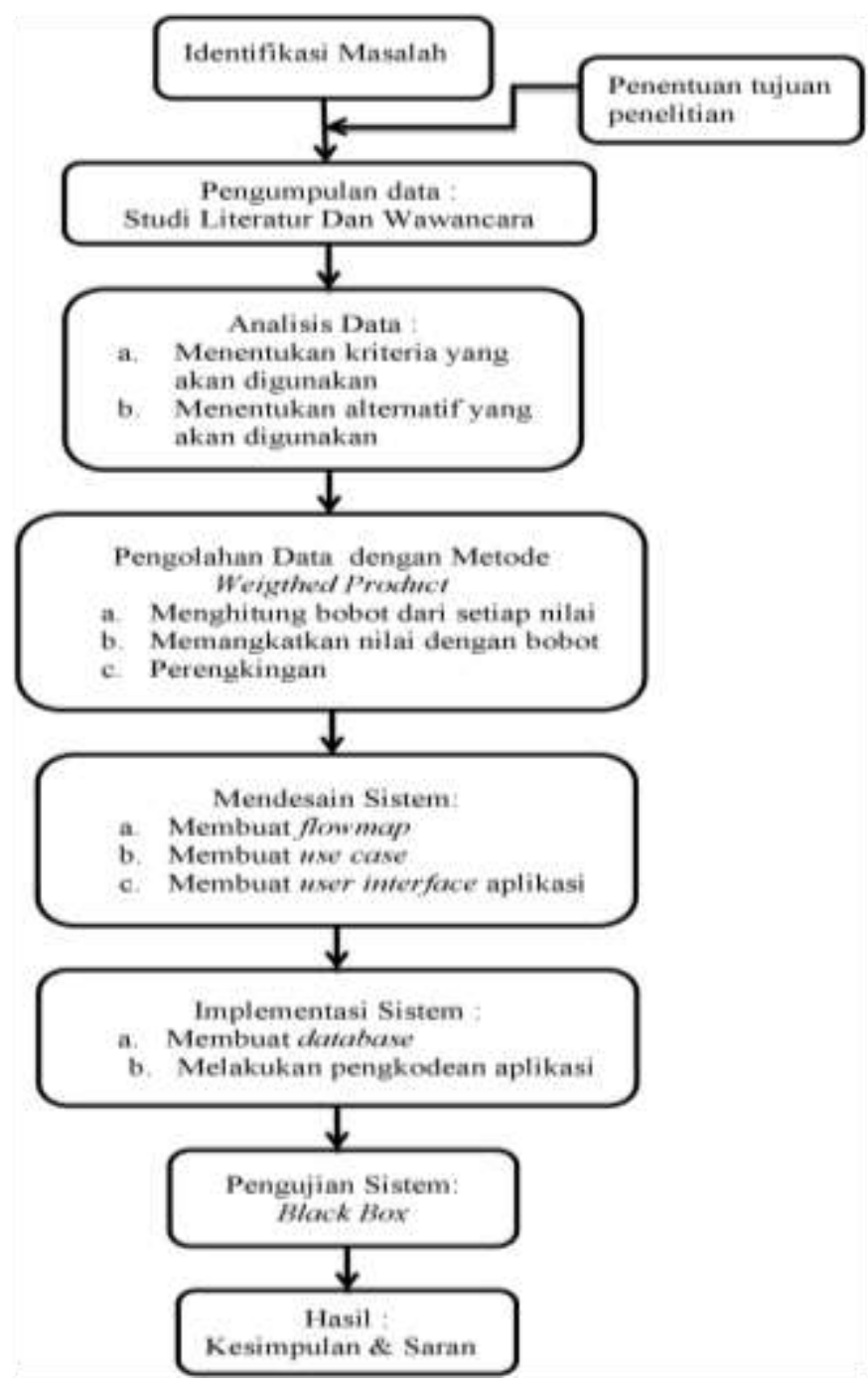

Gambar 1. Diagram Alur Metodologi Penelitian 


\subsection{Metode Weighted Product}

Multi Attribute Decision Making (MADM) adalah suatu metode yang digunakan untuk mencari alternatif paling optimal dari sejumlah alternatif optimal dengan kriteria tertentu[10]. Inti dari MADM adalah menentukan nilai bobot untuk setiap atribut, kemudian dilanjutkan dengan proses perangkingan yang akan menyeleksi alternatif yang sudah diberikan. Weighted Product (WP) merupakan salah satu metode yang digunakan untuk menyelesaikan masalah MADM[11]. Weighted Product (WP) adalah suatu metode yang menggunakan perkalian untuk menghubungkan rating atribut, dimana rating setiap atribut harus dipangkatkan dulu dengan bobot yang bersangkutan. Proses ini sama halnya dengan proses normalisasi[12].

Metode Weighted Product dapat membantu dalam mengambil keputusan kelayakan pemberian kredit, dengan menggunakan metode Weighted Product ini hanya menghasilkan nilai terbesar yang akan terpilih sebagai alternatif yang terbaik. Perhitungan akan sesuai dengan metode ini apabila alternatif yang terpilih memenuhi kriteria yang telah ditentukan[13]. Metode WP ini lebih efisien karena waktu yang dibutuhkan dalam perhitungan lebih singkat[14]. Bobot untuk atribut manfaat berfungsi sebagai pangkat positif dalam proses perkalian, sementara bobot biaya berfungsi sebagai pangkat negatif.

Weighted Product menggunakan teknik perkalian untuk menghubungkan rating atribut, dimana rating tiap atribut harus dipangkatkan terlebih dahulu dengan bobot atribut yang bersangkutan [15]. Langkah-langkah yang dilakukan dalam penyelesaian masalah menggunakan metode Weighted Product adalah :

1. Normalisasi/Perbaikan Bobot

$$
W j=\frac{\mathrm{Wj}}{\sum \mathrm{Wj}}
$$

Melakukan normalisasi / perbaikan bobot untuk menghasilkan nilai dimana 1, 2, ...., n adalah banyak alternatif. Menentukan kategori dari masing-masing kriteria yang termasuk dalam kriteria keuntungan atau kriteria biaya.

2. Menentukan Nilai Vektor $S$

$S i=\prod_{j=1}^{n} \quad X i j w j$, dengan $\mathrm{i}=1,2, \ldots, \mathrm{m}$

Keterangan:

$\Pi$ : product

$S i$ : skor / nilai dari setiap alternatif

$X i j$ : nilai alternatif ke- $i$ terhadap atribut ke- $j$

$W j$ : bobot dari setiap atribut atau kriteria

$n$ : Banyaknya kriteria.

Menentukan nilai vektor $\mathrm{S}$ dengan mengalikan seluruh kriteria dengan alternatif hasil normalisasi/perbaikan bobot yang berpangkat positif untuk kriteria keuntungan dan yang berpangkat negatif untuk kriteria biaya.

3. Menentukan Nilai Vektor V / Perangkingan

$$
V i=\frac{\prod_{j=1}^{n} X i j w j}{\prod_{j=1}^{n}(X j *) w j}
$$

Keterangan :

$V$ : Preferensi alternatif dianalogikan sebagai vektor $V$

$x$ : Nilai Kriteria

$w$ : Bobot kriteria/subkriteria

$i \quad$ : Alternatif

$j \quad$ : Kriteria

$n$ : Banyaknya kriteria

* : Banyaknya kriteria yang telah dinilai pada vektor $S$

Menentukan nilai vektor $V$ yang akan digunakan untuk perangkingan dari masing-masing jumlah nilai vektor $\mathrm{S}$ dengan jumlah seluruh nilai vektor $S$.

\section{ANALISA DAN PEMBAHASAN}

\subsection{Analisis Sistem Yang Akan Dibangun}

Analisis merupakan kegiatan penguraian suatu system yang utuh dan nyata kedalam bagian atau komponen yang bertujuan untuk mengidentifikasikan serta mengevaluasi masalah-masalah yang ada, yang bertujuan untuk mempelajari aktivitas system untuk mendapat gambaran yang menyeluruh dan permasalahan yang terjadi serta kebutuhan-kebutuhannya. 
Pada analisis ini akan dibahas langkah-langkah atau prosedur sistem yang akan digunakan atau dibangun untuk proses penentu kelayakan pemberian pinjaman Pensiun dengan menggunakan metode Weighted Product. Untuk lebih jelasnya Diagram Alur Dokumen (flowmap) berikut mendefinisikan hubungan proses antara bagian petugas kredit Pensiun dan Sistem yang akan membantu memberikan kelayakan pemberian kredit Pensiun.

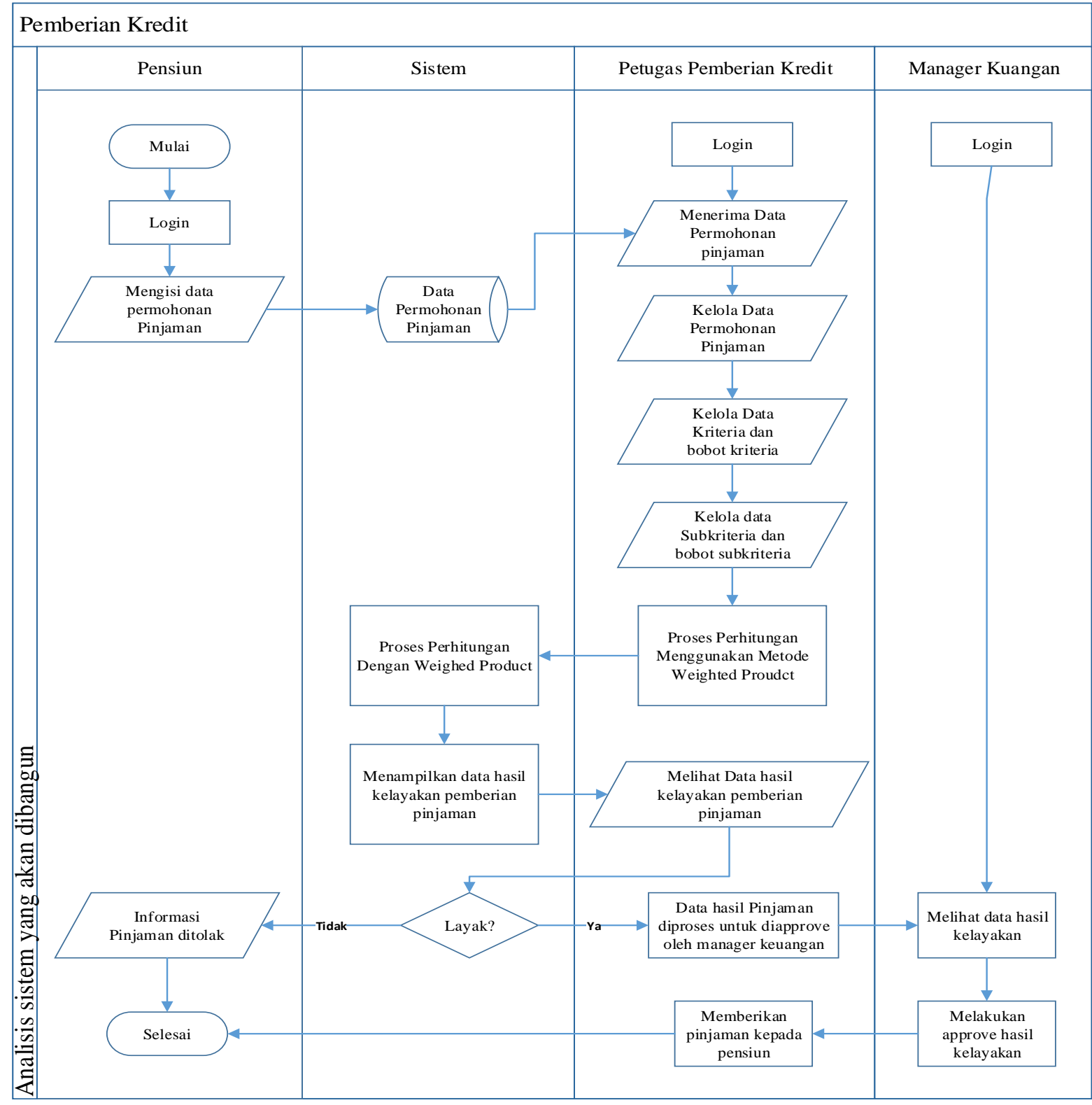

Gambar 2. Flowmap sistem yang akan dibangun

Adapun perancangan Unified Modeling Language (UML) adalah teknik untuk merancang sebuah sistem serta aplikasinya. UML adalah Bahasa yang menentukan, memvisualisasikan membangun, dan mendokumentasikan suatu sistem informasi yang akan dirancang. Usecase Diagram menggambarkan alur sistem secara ringkas dan menggambarkan kebutuhan fungsionalitas yang diharapkan oleh sebuah sistem. Sasaran pemodelan use case diantaranya adalah mendefinisikan kebutuhan fungsional dan operasional sistem dengan mendefinisikan skenario penggunaan yang disepakati antara pemakai dan pengembang. Berikut use case Diagram Sistem Kelayakan Pemberian Pinjaman Pensiun. 


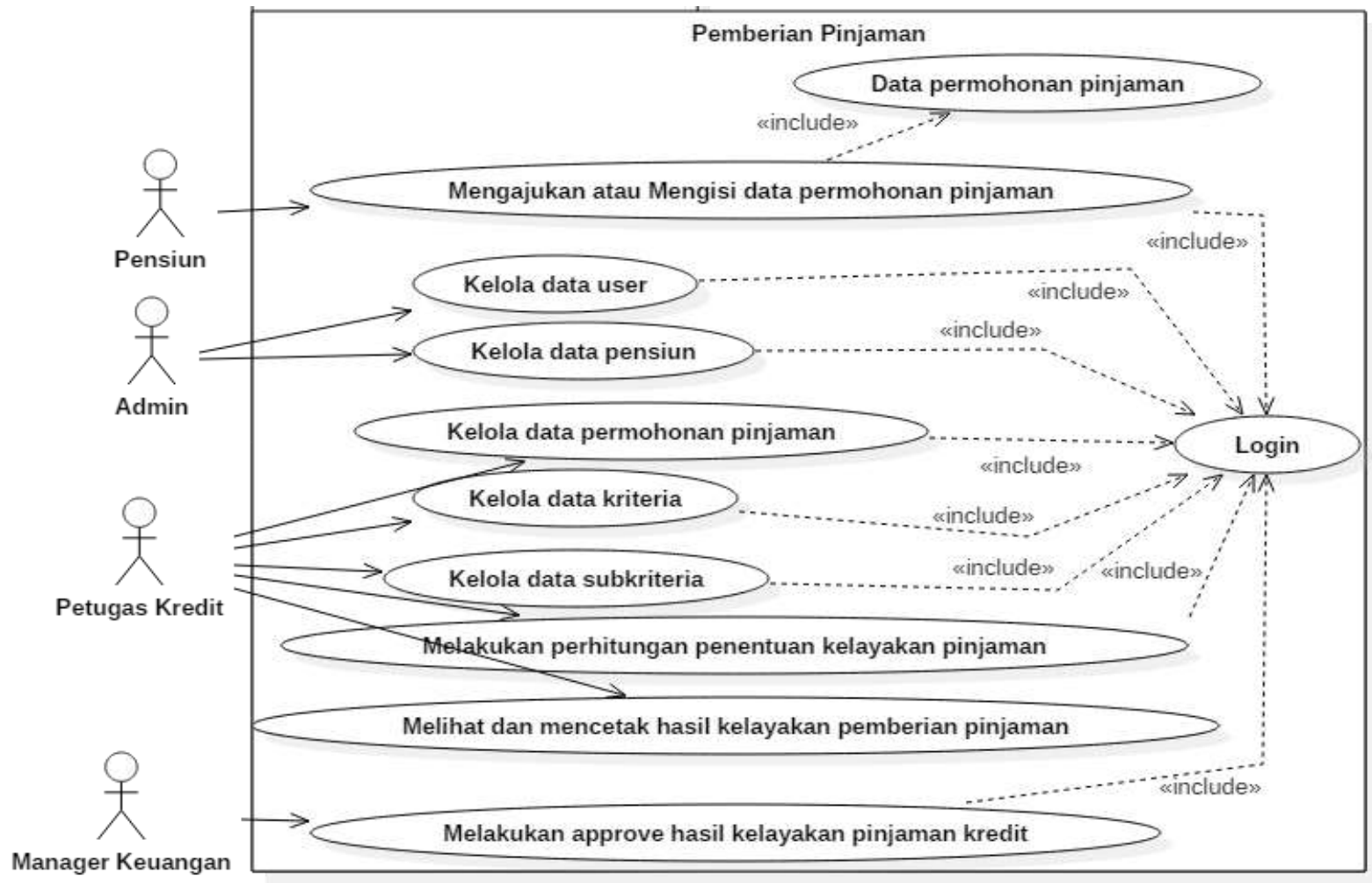

Gambar 3. Use Case Diagram

\subsection{Pembahasan}

Dalam pembahasan ini, peneliti akan melakukan pengkajian terhadap proses perhitungan menggunakan metode Weighted Product yang nantinya akan diterapkan pada sistem yang dibuat. Penerapan metode Weighted Product yang dilakukan untuk menentukan calon Pensiun yang layak untuk mendapatkan pinjaman kredit.

1. Penentuan Kriteria dan Bobot Kriteria

Kriteria-kriteria dideklarasikan terlebih dahulu, berikut pengelompokan kriteria berdasarkan syarat-syarat yang harus dipenuhi dalam pemberian kredit.

Nilai yang diinputkan pada kriteria-kriteria tersebut yaitu:
a. $\quad 5=$ Sangat Penting $(\mathrm{SP})$
b. $4=$ Penting $(\mathrm{P})$
c. $3=$ Cukup Penting $(\mathrm{CP})$
d. 2 = Kurang Penting (KP)
e. 1 = Sangat Kurang (SK)

Tabel 1. Data Kriteria

\begin{tabular}{cccc}
\hline No. & Kriteria & Keterangan & Bobot \\
\hline 1. & K1 & Besar Gaji & 5 \\
2. & K2 & Jumlah Pinjaman & 5 \\
3. & K3 & Usia & 4 \\
4. & K4 & Jangka Waktu & 3 \\
& & Kredit & \\
5. & K5 & Kredit ke-berapa & 3 \\
Total & & & 20 \\
\hline
\end{tabular}

2. Normalisasi atau Perbaikan Bobot Kriteria

Bobot dari data kriteria tersebut akan dinormalisasikan atau perbaikan nilai bobotnya dengan menggunakan persamaan (1).

Menghitung nilai normalisasi bobot atau perbaikan bobot $(\mathrm{Wj})$ berdasarkan nilai prioritas bobot setiap kriteria yang sudah ditentukan. Dari persamaan (1) maka nilai bobot yang dimiliki masing-masing kriteria dibagi dengan jumlah dari semua bobot kriteria.

Maka, untuk setiap kriteria didapatkan hasil bobot sebagai berikut:

Nilai awal $\mathbf{W}=[\mathbf{5 , 5}, \mathbf{4 , 3}, \mathbf{3}]$ 
a. Untuk normalisasi bobot kriteria Besar Gaji (K1)

$$
\mathrm{K} 1=\frac{5}{5+5+4+3+3}=\frac{5}{20}=0,25
$$

b. Untuk normalisasi bobot kriteria Jumlah Pinjaman (K2)

$$
\mathrm{K} 2=\frac{5}{5+5+4+3+3}=\frac{5}{20}=0,25
$$

c. Untuk normalisasi bobot kriteria Usia (K3)

$$
\mathrm{K} 3=\frac{4}{5+5+4+3+3}=\frac{4}{20}=0,2
$$

d. Untuk normalisasi bobot kriteria Jangka Waktu Kredit (K4)

$$
\mathrm{K} 4=\frac{3}{5+5+4+3+3}=\frac{3}{20}=0,15
$$

e. Untuk normalisasi bobot kriteria Kredit Ke-berapa (K5)

$$
\mathrm{K} 5=\frac{3}{5+5+4+3+3}=\frac{3}{20}=0,15
$$

\begin{tabular}{|c|c|c|c|}
\hline No. & Syarat atau Kriteria & Pembagian & Bobot \\
\hline \multirow[t]{4}{*}{1.} & Besar Gaji & $\leq 3$ juta & 2 \\
\hline & & $3<\times \leq 4$ juta & 3 \\
\hline & & $4<\times \leq 5$ juta & 4 \\
\hline & & $5<x \leq 6$ juta & 5 \\
\hline \multirow[t]{5}{*}{2.} & Jumlah Pinjaman & $\leq 10$ juta & 5 \\
\hline & & $20<x \leq 30$ juta & 4 \\
\hline & & $30<\times \leq 40$ juta & 3 \\
\hline & & $40<x \leq 50$ juta & 2 \\
\hline & & $50<\times \leq 60$ juta & 1 \\
\hline \multirow[t]{5}{*}{3.} & Usia & $\overline{55}$ & 5 \\
\hline & & 56 & 4 \\
\hline & & 57 & 3 \\
\hline & & 58 & 2 \\
\hline & & 59 & 1 \\
\hline \multirow[t]{3}{*}{4.} & Jangka Waktu Kredit & 1 tahun & 5 \\
\hline & & 2 tahun & 4 \\
\hline & & 3 tahun & 2 \\
\hline \multirow[t]{3}{*}{5.} & Kredit ke-berapa & 1 & 5 \\
\hline & & 2 & 3 \\
\hline & & 3 & 2 \\
\hline
\end{tabular}

2. Penentuan Subkriteria dan Bobot Subkriteria

Dari masing-masing kriteria yang sudah ditentukan maka selanjutnya tentukan subkriteria yang dimiliki oleh masing-masing kriteria.

Tabel 2. Subkriteria dan Bobot

3. Normalisasi atau Perbaikan Bobot Subkriteria

Untuk perihitungan normalisasi bobot subkriteria dengan menggunakan persamaan (1) sama seperti normalisasi bobot kriteria di atas yaitu nilai bobot yang dimiliki masing-masing subkriteria dibagi dengan jumlah dari semua bobot subkriteria.

Nilai awal Subkriteria dari Kriteria Besar Gaji, W $=[\mathbf{5 , 4 , 3 , 2}]$

a. Bobot subkriteria $\leq 3$ juta

$$
\mathrm{Wj} \leq 3 \text { juta }=\frac{2}{5+4+3+2}=\frac{2}{14}=0,142
$$

b. Bobot subkriteria $3<x \leq 4$ juta

$$
\mathrm{Wj} 3<x \leq 4 \mathrm{juta}=\frac{3}{5+4+3+2}=\frac{3}{14}=0,214
$$

c. Bobot subkriteria $4<x \leq 5$ juta

$$
\mathrm{Wj} 4<x \leq 5 \mathrm{juta}=\frac{4}{5+4+3+2}=\frac{4}{14}=0,285
$$

d. Bobot subkriteria $5<x \leq 6$ juta

$$
\mathrm{Wj} 5<x \leq 6 \mathrm{juta}=\frac{5}{5+4+3+2}=\frac{5}{14}=0,357
$$

Nilai awal Subkriteria dari Kriteria Jumlah Pinjaman, $W=[\mathbf{5 , 4 , 3 , 2 , 1}]$

a. Bobot subkriteria $\leq 10$ juta

$$
\mathrm{Wj} \leq 10 \mathrm{juta}=\frac{5}{5+4+3+2+1}=\frac{5}{15}=0,333
$$


Dan seterusnya..

4. Perhitungan Bobot Global

Perhitungan bobot global dikali hasil normalisasi bobot kriteria dengan hasil bobot subkriteria di atas.

a. Kriteria Besar Gaji $(\mathrm{K} 1)=0,25$

$\leq 3$ juta $=0,142 * 0,25=0,0355$

$3<\times \leq 4$ juta $=0,214 * 0,25=0,0535$

$4<\times \leq 5$ juta $=0,285 * 0,25=0,0712$

$5<\times \leq 6$ juta $=0,357 * 0,25=0,0892$

b. Kriteria Jumlah Pinjaman $(\mathrm{K} 2)=0,25$

$\leq 10$ juta $=0,333 * 0,25=0,0832$

Dan seterusnya..

5. Data Awal Pensiun

Berikut ini merupakan data awal dari alternatif atau data Pensiun yang akan ditentukan mana yang layak.

Tabel 3. Data Pembobotan Alternatif

\begin{tabular}{cccccc}
\hline Nama & Besar Gaji & Jumlah Pinjaman & Jangka Waktu Kredit & Usia & Kredit ke-berapa \\
\hline P1 & 3.630 .900 & 60.000 .000 & 58 & 3 Tahun & 3 \\
P2 & 4.275 .000 & 10.000 .000 & 55 & 2 Tahun & 1 \\
P3 & 5.160 .200 & 20.000 .000 & 56 & 1 Tahun & 1 \\
P4 & 2.604 .800 & 40.000 .000 & 59 & 3 Tahun & 3 \\
P5 & 3.927 .200 & 40.000 .000 & 58 & 3 Tahun & 3 \\
P6 & 2.819 .900 & 30.000 .000 & 59 & 3 Tahun & 3 \\
P7 & 5.702 .300 & 20.000 .000 & 55 & 1 Tahun & 1 \\
P8 & 4.341 .500 & 10.000 .000 & 55 & 2 Tahun & 2 \\
P9 & 2.527 .300 & 50.000 .000 & 59 & 3 Tahun & 1 \\
P10 & 4.944 .700 & 10.000 .000 & 55 & 2 Tahun & 1 \\
P11 & 5.165 .100 & 50.000 .000 & 59 & 3 Tahun & 2 \\
\hline
\end{tabular}

Dari data awal diatas maka ditentukan bobot untuk setiap alternatif dan setiap kriteria pensiun berdasarkan penentuan bobot pada tabel 2 .

Tabel 4. Data Pembobotan Alternatif

\begin{tabular}{cccccc}
\hline Alternatif & Besar Gaji & Jumlah Pinjaman & Jangka Waktu Kredit & Usia & Kredit ke-berapa \\
\hline P1 & 3 & 1 & 2 & 2 & 2 \\
P2 & 4 & 5 & 5 & 4 & 5 \\
P3 & 5 & 4 & 4 & 5 & 5 \\
P4 & 2 & 2 & 1 & 2 & 2 \\
P5 & 3 & 2 & 2 & 2 & 2 \\
P6 & 2 & 3 & 1 & 2 & 2 \\
P7 & 5 & 4 & 5 & 5 & 5 \\
P8 & 4 & 5 & 5 & 4 & 3 \\
P9 & 2 & 1 & 1 & 2 & 5 \\
P10 & 4 & 5 & 5 & 4 & 5 \\
P11 & 5 & 1 & 1 & 2 & 3 \\
\hline
\end{tabular}

6. Perhitungan Vektor $\mathrm{S}$

Proses kuadratkan data alternatif dengan bobot global masing masing subkriteria yang telah didapatkan.

Perhitungan vektor S menggunakan persamaan (2).

Maka untuk perhitungan vektor $\mathrm{S}$ setiap alternatif adalah
1. S1 $=\left(3^{0,0535}\right)\left(1^{0,0165}\right)\left(2^{0,0266}\right)\left(2^{0,0271}\right)\left(2^{0,03}\right)$
$=(1.060537)(1)(1.018608)(1.018961)(1.021012)=\mathbf{1 . 1 2 3 8 8 5}$
2. S2 $=\left(4^{0,0712}\right)\left(5^{0,0832}\right)\left(5^{0,0666}\right)\left(4^{0,0544}\right)\left(5^{0,075}\right)$
$=(1.103739)(1.143284)(1.113144)(1.078330)(1.128295)=\mathbf{1 . 7 0 9 0 1 6}$ Dan seterusnya..

Jumlah total vektor S adalah P1 + P2 + P3 + P4 + P5 + P6 + P7 + P8 + P9 + P10 + P11 = $1.123885+$ $1.709016+1.715680+1.091195+1.150046+1.126498+1.774019+1.591452+1.178328+$

$1.710016+1.235878=\mathbf{1 5 . 4 0 6 0 1 3}$

7. Perhitungan Vektor V 
Menentukan nilai vektor $\mathrm{V}$ yang akan digunakan untuk perangkingan dari masing-masing jumlah nilai vektor S dengan jumlah seluruh nilai vektor $S$. Berikut ini perhitungan vektor V menggunakan persamaan (3).

Maka untuk perhitungan vektor $\mathrm{V}$ setiap alternatif adalah

1. $\mathrm{V} 1=\frac{1.123885}{\mathbf{1 5 . 4 0 6 0 1 3}}=\mathbf{0 . 0 7 2 9 5 1}$

2. $\mathrm{V} 2=\frac{1.709016}{\mathbf{1 5 . 4 0 6 0 1 3}}=\mathbf{0 . 1 1 0 9 3 1}$ Dan seterusnya..

8. Hasil Akhir

Dari perhitungan diatas maka didapat hasil sebagai berikut.

Tabel 5. Hasil Akhir

\begin{tabular}{cccc}
\hline Alternatif & Keterangan & Nilai Akhir & Rangking \\
\hline P1 & Hannan & $\mathbf{0 . 0 7 2 9 5 1}$ & Tidak Layak \\
P2 & Peni & $\mathbf{0 . 1 1 0 9 3 1}$ & Layak \\
P3 & Anang & $\mathbf{0 . 1 1 1 3 6 4}$ & Layak \\
P4 & Rahmawati & $\mathbf{0 . 0 7 0 8 2 9}$ & Tidak Layak \\
P5 & Lena & $\mathbf{0 . 0 7 4 6 4 9}$ & Tidak Layak \\
P6 & Nia Rosnia & $\mathbf{0 . 0 7 3 1 2 0}$ & Tidak Layak \\
P7 & Renni & $\mathbf{0 . 1 1 5 1 5 1}$ & Layak \\
P8 & Farah & $\mathbf{0 . 1 0 3 3 0 0}$ & Layak \\
P9 & Retno Dwi & $\mathbf{0 . 0 7 6 4 8 4}$ & Tidak Layak \\
P10 & Didit Adi & $\mathbf{0 . 1 1 0 9 9 6}$ & Layak \\
P11 & Michael & $\mathbf{0 . 0 8 0 2 2 0}$ & Tidak Layak \\
\hline
\end{tabular}

Nilai terbesar atau prioritas nilai yang diambil untuk menentukan yang layak adalah dengan nilai total 0,090. Jadi nilai dibawah 0,090 dinyatakan tidak layak.

\section{IMPLEMENTASI}

Implementasi sistem merupakan bagian yang menerangkan tentang penerapan dan hasil dari perhitungan sistem kelayakan pemberian pinjaman kepada pensiun.

1. Halaman Data Kriteria

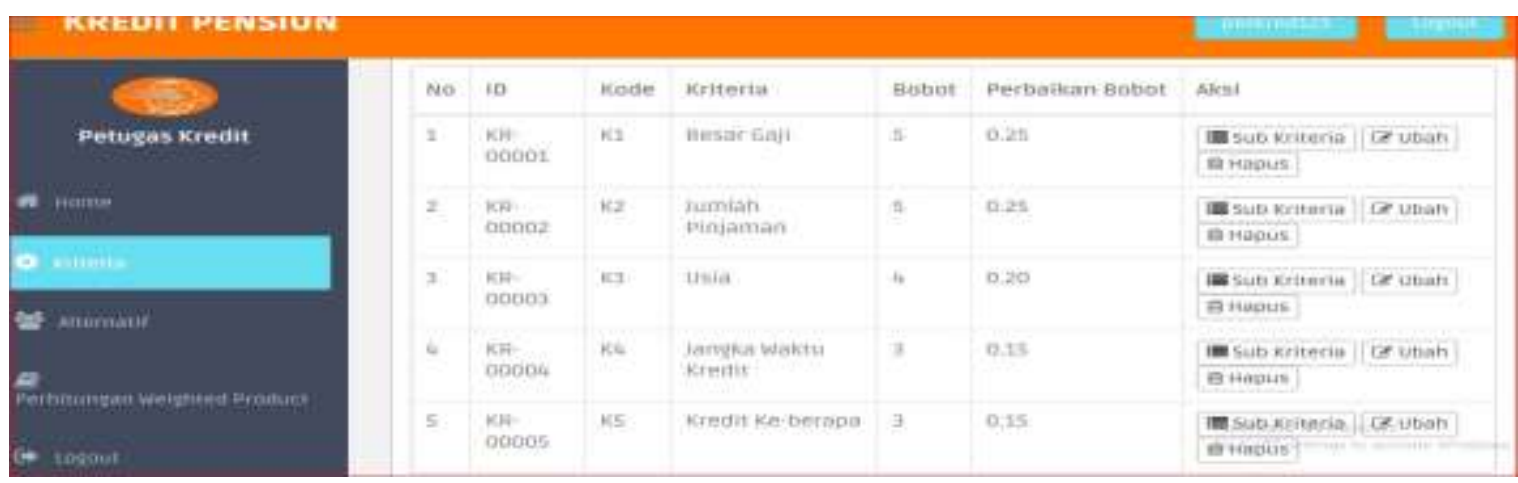

Gambar 4. Halaman Data Kriteria

2. Halaman Data Subkriteria

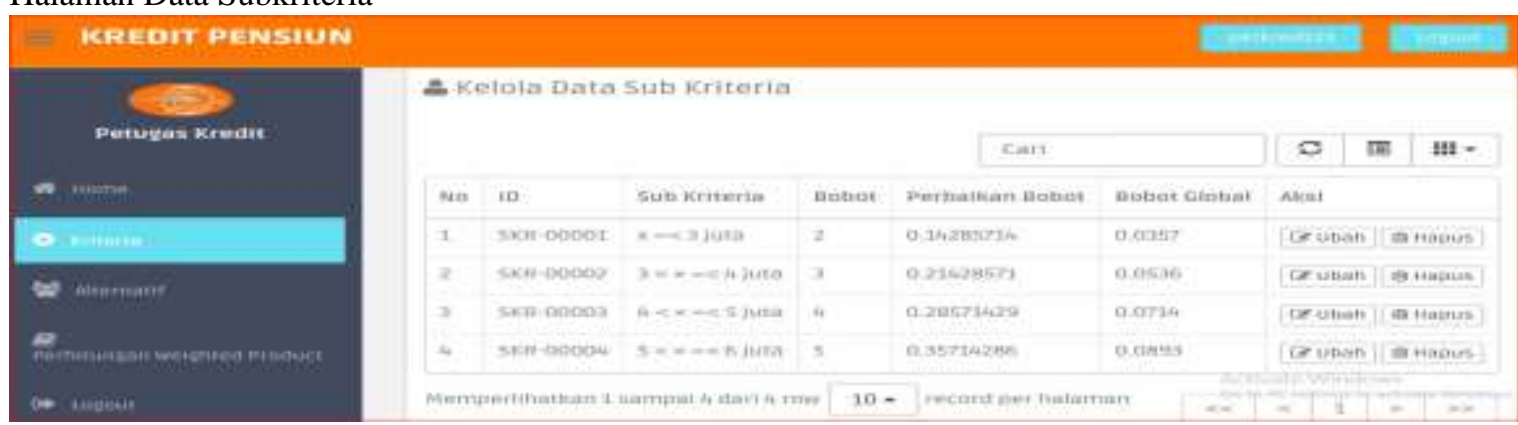

Gambar 5. Halaman Data Subkriteria

3. Halaman Data Alternatif 


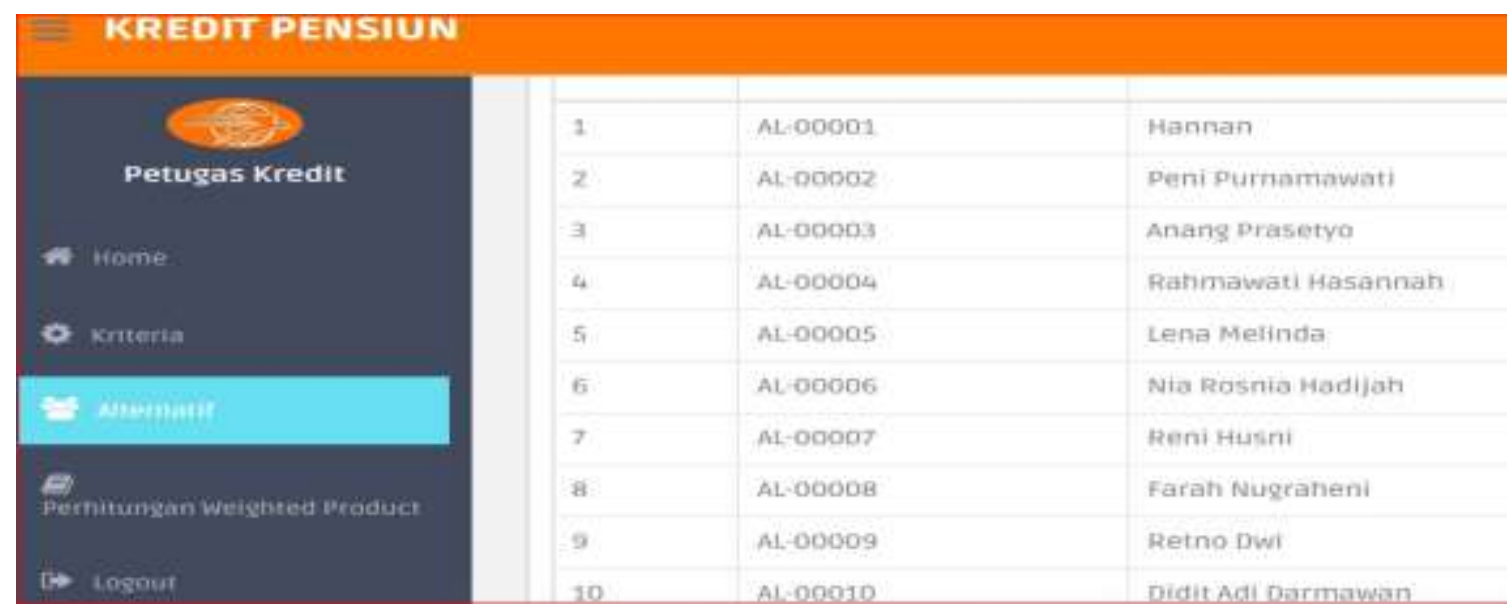

Gambar 6. Halaman Nilai Alternatif

4. Halaman Weighted Product Vektor V Hasil Kelayakan

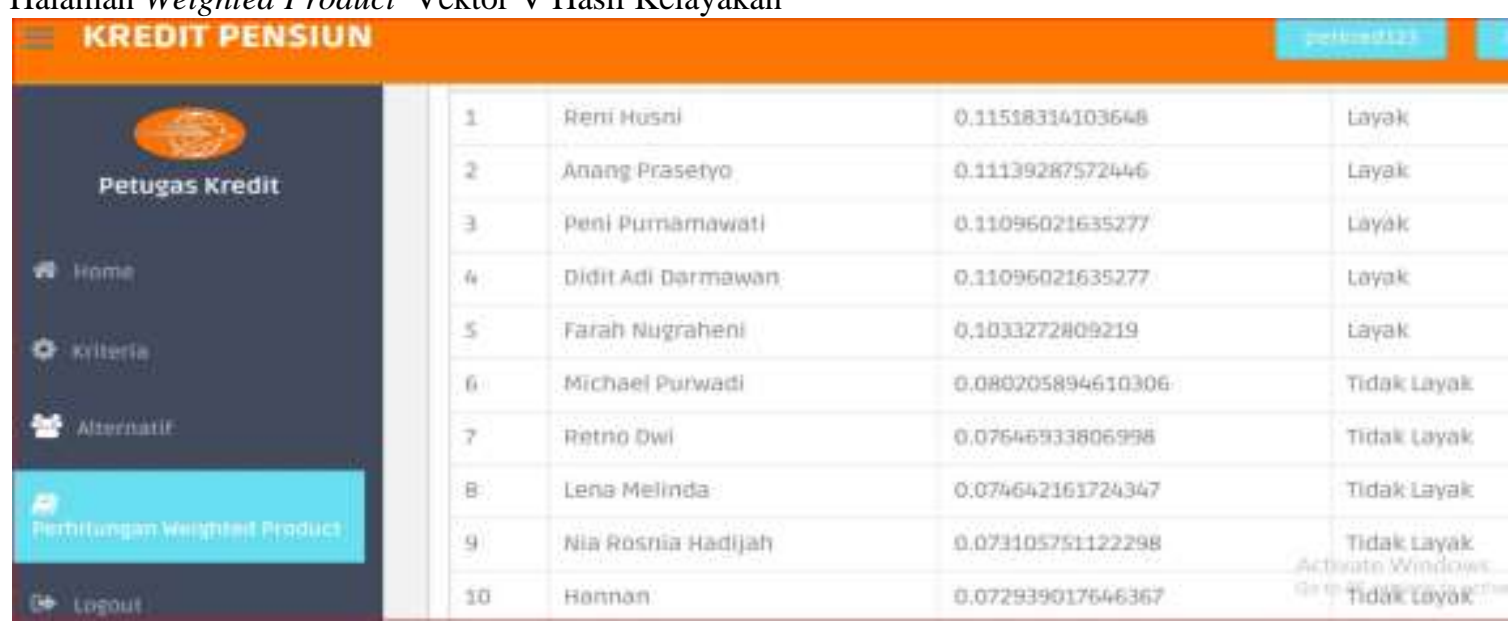

5. Halaman Approve

Gambar 7. Halaman Weighted Product

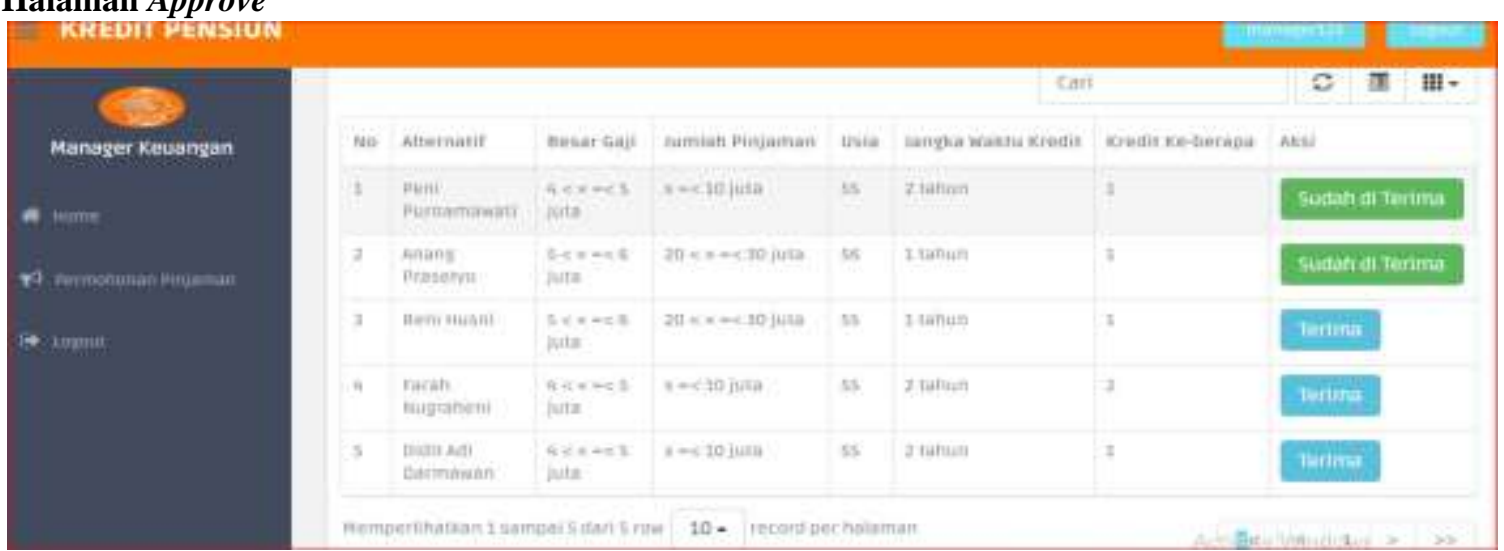

Gambar 9. Halaman Approve

\section{KESIMPULAN}

Pada penelitian ini penulis mengharapkan beberapa kesimpulan, diantaranya sebagai berikut:

1. Dengan penerapan metode Weighted Product (WP) maka dapat menentukan Pensiun yang berhak mendapatkan pinjaman kredit berdasarkan kriteria-kriteria yang ditetapkan. Kriteria-kriterianya, yaitu besar gaji, umur, jumlah pinjaman, jangka waktu kredit, dan kredit keberapa.

2. Sistem kelayakan pemberian kredit dapat menghasilkan keputusan mengenai pemberian pinjaman kepada pensiun dengan menggunakan metode Weighted Product.

Maka dari hasil penelitian ini telah menunjukkan bahwa penerapan metode Weighted Product dapat membantu dan mendapatkan hasil dalam menentukan Pensiun yang berhak untuk diberikan pemberian kredit pensiun 
dengan berdasarkan kriteria-kriteria atau syarat serta bobot-bobot yang digunakan dalam perhitungan dan dapat diterapkan pada Kantor Pos Bandung agar dapat mempermudah dalam menentukan pensiun yang berhak untuk diberikan kredit pensiun.

\section{REFERENCES}

[1] L. Amelia and D. Marlius, "Pengendalian kredit dalam upaya menciptakan bank yang sehat pada pt. bank pembangunan daerah sumatera barat cabang utama padang," 2018.

[2] M. Kadarisman, "Menghadapi pensiun dan kesejahteraan psikologis pegawai negeri sipil," Civil Service Journal, vol. 5, no. 2 November, 2015.

[3] T. R. Adianto, Z. Arifin, and D. M. Khairina, "Sistem pendukung keputusan pemilihan rumah tinggal di perumahan menggunakan metode simple additive weighting (saw)(studi kasus: Kota samarinda)," Prosiding 2nd SAKTI, 2017.

[4] K. Yasdomi, "Sistem pendukung keputusan pemberian kredit modal usaha menggunakan metode weighted product (studi kasus pada bank danamon simpan pinjam ujung batu)," Riau Journal Of Computer Science, vol. 1, no. 1, pp. 92-105, 2015.

[5] E. Suryeni, Y. H. Agustin, and Y. Nurfitria, "Sistem pendukung keputusan kelayakan penerimaan bantuan beras miskin dengan metode weighted product di kelurahan karikil kecamatan mangkubumi kota tasikmalaya," Proceedings Konferensi Nasional Sistem dan Informatika (KNS\&I), 2015.

[6] O. Fajarianto, M. Iqbal, and J. T. Cahya, "Sistem penunjang keputusan seleksi penerimaan karyawan dengan metode weighted product," Jurnal Sisfotek Global, vol. 7, no. 1, 2017.

[7] K. T. Naramessakh and C. Prianto, "Otomatisasi keputusan pemberian kredit pensiun menggunakan metode weighted product," EFISIENSI-KAJIAN ILMU ADMINISTRASI, vol. 16, no. 1, pp. 33-48, 2019.

[8] Hafiz Ridha. Implementasi twitter bootstrap pada codeigniter. Retrieved Octeober, 4:2013, 2016.

[9] Prastuti Sulistyorini. Pemodelan visual dengan menggunakan uml dan rational rose. Dinamik, 14(1), 2015.

[10] J. Simarmata, T. Limbong, M. Aritonang, and S. Sriadhi, "Sistem pendukung keputusan pemilihan guru bidang studi komputer menggunakan metode simple additive weighting (saw)," CESS (Journal of Computer Engineering, Science and System), vol. 3, no. 2, pp. 186-190, 2018.

[11] Y. Zai, M. Mesran, and E. Buulolo, "Sistem pendukung keputusan untuk menen-tukan buah rambutan dengan kualitas terbaik menggunakan metode weighted product (wp)," JURNAL MEDIA INFORMATIKA BUDIDARMA, vol. 1, no. 1, 2017.

[12] N. Nurjannah, Z. Arifin, and D. M. Khairina, "Sistem pendukung keputusan pembelian sepeda motor dengan metode weighted product," J. Inform. Mulawarman, vol. 10, no. 2, pp. 2-6, 2015.

[13] M. Muslihudin and R. F. Andriyanti, "Implementasi metode weighted product menentukan beasiswa bidik misi stmik pringsewu," JURNAL TEKNIK INFORMATIKA DAN SISTEM INFORMASI, vol. 4, no. 2, pp. 156-163, 2018.

[14] J. Riyanto, "Perbandingan metode weighted product (wp) dan simple additive weighting (saw) penilaian kinerja guru pada madrasah ibtidaiyah negeri 3 jakarta," Jurnal Informatika Universitas Pamulang, vol. 2, no. 4, pp. 179-183, 2017.

[15] K. Safitri, F. T. Waruwu, and M. Mesran, "Sistem pendukung keputusan pemilihan karyawan berprestasi dengan menggunakan metode analytical hieararchy process (studi kasus: Pt. capella dinamik nusantara takengon)," Media Informatika Budidarma, vol. 1, no. 1, 2017. 